\title{
The antecedents of comparative differences in union presence and engagement: evidence from coordinated and liberal market contexts
}

Article

Accepted Version

Brookes, M., Wood, G. and Brewster, C. (2019) The antecedents of comparative differences in union presence and engagement: evidence from coordinated and liberal market contexts. International Studies of Management \& Organization, 49 (4). pp. 389-401. ISSN 1558-0911 doi:

https://doi.org/10.1080/00208825.2019.1646488 Available at https://centaur.reading.ac.uk/85864/

It is advisable to refer to the publisher's version if you intend to cite from the work. See Guidance on citing.

To link to this article DOI: http://dx.doi.org/10.1080/00208825.2019.1646488

Publisher: Informa UK Limited

All outputs in CentAUR are protected by Intellectual Property Rights law, including copyright law. Copyright and IPR is retained by the creators or other copyright holders. Terms and conditions for use of this material are defined in the End User Agreement. 


\section{www.reading.ac.uk/centaur}

\section{CentAUR}

Central Archive at the University of Reading

Reading's research outputs online 


\section{The Antecedents of Comparative Differences in Union Presence and Engagement: Evidence from Coordinated and Liberal Market Contexts}

Michael Brookes* Hertfordshire Business School, University of Hertfordshire, UK. m.brookes2@herts.ac.uk

Geoffrey Wood, Essex Business School, University of Essex, UK. gtwood@essex.ac.uk

Chris Brewster, Henley Business School, University of Reading, UK. c.j.brewster@henley.ac,uk

\section{*Corresponding author}

Abstract: This study employs a large on-going survey database to explore the antecedents of comparative differences in union representation and the extent to which employers engage with them at the workplace, and how this has changed over time. It finds that amongst organizations employing more than 100 employees, there has been no uniform decline in the presence of unions, or engagement by employers with them at the workplace. In other words, although we do not measure the range of topics covered or the impact of such engagement, it is clear that neither the neo-liberal nor the more critical theory suggestions that systems are naturally converging to a common model of minimal union presence and engagement receives much support. Collective employment relations are influenced by comparative capitalisms and, to a lesser extent, legal systems and remain a significant feature of many continental European economies.

Key Words: Union presence; Engagement with unions; Convergence; Comparative HRM; Varieties of Capitalism; Institutionalism

\section{INTRODUCTION}

There is a growing body of international literature that focuses on the effects of institutional mediation on employment relations practice, and on possible trends to convergence (Brewster 2006; Lane and Wood 2009; Mayrhofer, Brewster, Morley and Ledolter 2011). Much of the literature outlining and contrasting employment relations practices only looks at a particular 
point of time. Clearly, to draw any conclusions about possible convergence it is important either to have data from different times or to have data that looks back over time. Much of the extant literature confuses what are two different concepts when discussing convergence (see Mayrhofer and Brewster 2005; Mayrhofer, Müller-Camen, Ledolter, Strunk and Erten 2002). The dictionary defines convergence as existing when the analyzed variables develop over time in a way that would, eventually, lead to a common end point: the differences between the units - countries in our analysis - decrease. According to Friedman $(1992,2130)$ "the real test of a tendency to convergence would be in showing a consistent diminution of variance." Sometimes convergence is confused with the other concept: similar trends. This type of 'convergence' occurs when the developments of variables in units of analysis over time are pointing in the same direction. Thus, pertinently for our analysis here, it is well-known both that the membership of trade unions is declining in most countries over the last 25 years, but also that there is some consistency in differences between countries in their levels of union membership (Checchi and Visser 2005; Hall and Soskice 2001): there is evidence of common trends but no evidence of convergence. The distinction is important because it explains the danger of drawing conclusions from similar trends as if they are evidence of convergence.

We draw upon successive waves of an international survey of HR managers, in order to explore tendencies and changes, comparing and contrasting these with the predictions of the socio-economic and employment relations literature. A key aim of this research is to explore the extent to which there has been a shift away from collectivism and to assess the antecedents of any such change in different institutional contexts. More specifically, we explore the extent to which there has been a move towards non-unionism across larger organizations in the developed world, epitomized by a decline in collective employment relations. We find the persistence of diversity but, at the same time, evidence of uneven and varied change in specific contexts. We locate this finding within recent developments in the socio-economic literature.

\section{convergence and diffusion as a product of union decline}

In an influential book, Katz and Darbishire (2000) explored the extent to which national employment relations practices are converging, based on a cross-section of developed Western European, Far Eastern and North American economies. They found a persistence of difference 
but suggested that diversity was growing within all national economies and sectors; at the same time, they encountered a common trend to weaker unions, and centralized bargaining, and heterogeneity in pay systems (Katz and Darbishire 2000; Marsden 2001, 683). They conclude that collective bargaining has become heterogeneous between and within countries (Katz and Darbishire 2000). In other words, not only has the basis of union representation - and the extent to which employers engage with them - eroded, but there is also greater diversity in the form the latter assumes. A range of other arguments support this point of view, and/or are even more explicitly pessimistic. For example, Turner (2009) notes that the use of new strategies by German unions points to the extent to which institutional stability cannot be assumed and that action by key players can impact on the broader system (c.f. Colvin 2003).

Moody (1997) argues that there has been a general convergence around the hardline antiunion practices. There is evidence that unions have become much weaker even in contexts where historically they were quite strong. For example, Doellgast, Holtgrewe and Deery (2009) argue that, in conjunction with the works council system, unions remain effective in Germany in supporting worker rights, but that outsourcing is a mechanism for firms to opt out from some of the imposed strictures. In turn, the latter might undermine the position of unions across society. Looking at the German context, Turner (2009) argues that an over-reliance on institutional supports has made for complacency in the trade unions. In short, union representation and the extent to which employers engage with them have both declined.

Other writers, such as Godard (2006), have argued that the trend towards a decline in union representation and collective bargaining reflects the actions of neo-liberal governments and the general hegemony of neo-liberal ideologies. Marsden (2001) argues that there are some brakes on this process: renegotiation of the terms and conditions of work and employment and how they are negotiated undermine implicit rules and, on an individual basis, erode trust. In contrast, the retention of a collective element allows for meaningful compromises by both sides, even if the price is the erosion of some flexibility. Godard (2003) cautions against the view that convergence towards low labor standards are inevitable; it is possible, for example, for law to arrest or accelerate this process, citing the differences between the USA and Canada. This would suggest that national institutional systems are quite resilient. Indeed, there is recent evidence from Europe that the process of liberalization in coordinated markets may be over-estimated; for 
example, Thelen (2014) highlights the relative resilience of the German model and the underlying basis of collectivism. In other words, there has been a persistence of difference in both union representation and the extent to which employers engage with them.

\section{PERSISTENT DIFFERENCES: THE VARIETIES OF CAPITALISM LITERATURE}

This raises the question as to whether national institutional factors exert a persistently different effect on national employment relations practice. The Varieties of Capitalism (VoC) literature (Hall and Soskice 2001) argues that there are persistent differences between liberal market economies (the developed Anglo-Saxon economies, the LMEs) and coordinated market economies (the Rhineland economies, Scandinavia, Japan, the CMEs).

A central concept in the VoC literature is that of complementarity: in other words, that specific institutional forms and combinations of practices will work together better than they would on their own. This allows systems to build on their respective strengths and, indeed, to compensate for any inherent weaknesses (Crouch 2005). Other strands of the VoC literature, which may currently have some resonance, have argued that liberal markets are excessively short-term, which has ultimately detrimental effects for firms and their stakeholders (c.f. Lincoln and Kalleberg 1990; Dore 2000). In LMEs, shareholder value has primacy: this means that firms will orientate their activities to short term returns. Whilst this may make for labor repression, it may also facilitate high-technology activities with generically skilled highly mobile workforces (Thelen 2001). Central to liberal market economies is insecure and individualized employment contracting (Hall and Soskice 2001; Tregaskis and Brewster 2006). In CMEs, different stakeholder interests are reconciled to a very much greater extent: they work on compromise, rather than a zero-sum game, underpinned by a greater emphasis on centralized bargaining and trade-offs. This, in turn, makes for more cooperative work and employment relations, characterized by security of tenure, organization-specific human capital development and collective voice mechanisms (Brewster, Wood, Croucher and Brookes 2007).

The CME/ LME categories are quite broad; other accounts have drawn attention to many more varieties of capitalism (Amable 2003; Whitley 1999). Amable (2003:104-5) focuses particularly on the case of continental Europe, drawing a distinction between 'continental 
European' (NW European 'Rhineland' capitalism), and social democratic (or Scandinavian') capitalism. The latter category differs partly in that a weaker security of tenure is often compensated for by a greater emphasis on often-state-sponsored continuous skills development, and, above all, through persistently higher levels of collective representation.

More recent developments and extensions of the $\mathrm{VoC}$ literature point to the uneven, episodic and often experimental nature of systemic change (Hollingsworth 2006; Lane and Wood 2009). It is evident that both more coordinated varieties of capitalism and neo-liberal economies have had to face the possibility of far reaching changes in regulation and practice. Recent work has highlighted the effects of politics (Hancke, Rhodes and Thatcher 2007), and the process of experimentation. In practice, change may be about hybridization (the mixing of practices from different models (as is taking place in CMEs), or 'endo-metabalizm', internal development, for example, in LMEs becoming ever more extreme (Boyer 2006, 54). As Teague (2009) argues, this means that radical systemic change is unlikely; change is more likely to be incremental, uneven and open ended. In short, what the most recent literature on comparative capitalism suggests is that even as national archetypes have evolved, and although there is a general trend towards liberalization, the relative differences between them have persisted: if CMEs have liberalized, LMEs have become ever more extreme versions of themselves.

The overall theme underpinning all of this is that the union presence, and the degree of their formal engagement with employers, represents a function of the environment in which they operate, and how it is changing. A key issue still remains unresolved: how the behavior of unions and firms might be expected to evolve within differing environments. Clearly, within a framework more conducive to unions, they are more likely to secure a place at the workplace, and employers are likely to be more willing to communicate and exchange views through the trade union representatives. As a consequence, these factors will form the basis of our empirical measure of union presence, and their degree to which employers will formally engage with them.

\section{Statement of Hypotheses}

Drawing on the above discussion of theories of comparative difference and change we offer a number of hypotheses. 
First, it can be argued that there is a general tendency towards union decline, with this being evidenced by both a fall in union membership as well as employers being less willing to engage with them. This is reflected in the reduced efficacy of the institutional supports of representation (Turner 2009).

Hypothesis 1: There is a trend towards a general decline in both union presence, and in the relative willingness of employers to engage with them, regardless of national institutional setting.

Alternatively, it can be argued that any changes are likely to be modest and unlikely to constitute ruptures from established ways of doing things. Different types of capitalism are likely to retain their distinct characteristics (Thelen 2009): the unionization and employer engagement with unions remains persistently higher in CMEs.

Hypothesis 2a: There are ongoing differences in both union presence and the relative willingness of employers to engage with them across institutional settings such that CME firms show higher levels of union presence and greater willingness of employers to engage with them relative to their LME counterparts.

In moving beyond the LME and CME archetypal models, Amable (2003) argues that employment relations practices are likely to differ not only between liberal market economies and more coordinated ones but,within the latter category, between (Scandinavia) social democratic capitalism and continental European capitalism. In the latter, unions will not be quite as strong as in the (Scandinavian) social democracies, given differences in both their legal environments and social conventions (Amable 2003). Hence:

Hypothesis 2b: There are ongoing differences in union presence, and in the relative willingness of employers to engage with them between LMEs, continental European and social democratic capitalism, with unions weakest in LMEs and strongest in social democracies. 
An alternative view is that rather than a status quo, there has been a general decline in the presence of unions with the workplace, albeit that the level of unionization has persisted in proportionate terms (Streeck, 2010). In other words, whilst systems are retaining differences, all are liberalizing, making for a general picture of union decline. Hence:

Hypothesis 3: Although there is a general trend towards decline in both union presence and in the relative willingness of employers to engage with them, the relative difference between various types of capitalism has persisted.

\section{METHODOLOGY}

We assess variations in the relationship between institutions and employment relations through using the repeating Cranet survey of senior HR managers, which now contains evidence on policies and practices within private and public sector organizations in most European countries (Brewster, Mayrhofer and Morley 2004). The use of management-sourced information to focus on a single issue, changes in union-organization relations, is not unproblematic. In particular, it limits our ability to report explicit practice within the organization and to assess employee perceptions. However, in return, it enables us to compare organizational level policies across a range of different countries and, hence, institutional settings. Cranet only covers organizations with more than 100 employees; the exclusion of smaller organizations means that trends in that area are not covered, making for rather different results to national level surveys such as the Workplace Employment Relations Survey in the UK. However, given that unions are more likely to be represented in larger firms, Cranet does provide particularly valuable insights into the effects of union decline in this area.

\section{Sampling}

The data set used here cover five waves of the Cranet survey (i.e.1991; 1995; 1999/2000; 2003/4 and 2009). The data for each country are representative with respect to size of industrial sectors by employment, with each subsequent cross-sectional wave being adjusted to reflect changes in the relative size of industrial sectors (Brewster et al. 2007). Thus, the sample remains representative across the whole period considered. For the purpose of this study data from the UK, Germany and Sweden are used to test our hypotheses: in each case representing the largest 
European example of a liberal market economy, continental European capitalism and social democratic capitalism respectively. Beyond this, the UK is regularly held up as the quintessential LME in Europe, and Germany is seen as the archetypical continental European CME. Indeed, in some of the key varieties of capitalism texts (for example, Hall and Soskice 2001; Thelen 2009) the discussion is almost as much about Germany as it is about coordinated market economies. The Germany economy makes up a hugely disproportionate percentage of the general discussion about CMEs. Among the Scandinavia social democracies, flexicurity (Wilthagen and Tros 2004) is less advanced in Sweden, which arguably, makes it similarly the most quintessential example of a Scandinavian social democracy. Denmark is typically held up as a flexicurity economy and hence is atypical of the category. Sweden is not only a larger economy but more typical.

The data include 9359 observations, with the breakdown by country and year as reported below in Table 1. Although the data are skewed towards the UK, with over half of the sample from UK firms, the sub-samples for each country in each year remain representative by industrial sector.

\section{TABLE 1 ABOUT HERE}

\section{Model}

The empirical analysis explores the relationship between (1) union representation and (2) the relative willingness of employers to engage with them, as well as time and different national settings. For the purpose of the empirical model a scale is created that simultaneously captures both of these and reflects the extent of union power and influence within the organization. For this purpose, a Mokken non-parametric scale is constructed from the binary responses to 4 key questions, these being: (1) Are over 50\% of employees members of a union? (2) Does management perceive that unions have an influence within the organization? (3) Does management communicate to employees on key issues through trade union representatives? and (4) Do employees communicate their views to management through trade union representatives?

Fifty percent is, in many national contexts, the legal benchmark for trade union representivity and recognition (Wilkinson, Wood and Deeg, 2014). In addition to collective bargaining, engagement with unions may involve ongoing communications; alternatively, the use 
of non-union forms of communication may dilute the role of unions (Brewster et al. 2007). The scale is weighted to reflect the proportion of positive responses to each question and the resultant scale is a continuous variable ranging from 0 to 100 , with higher values indicating that unions have greater scope to influence activities and decisions within that firm. The union influence scale is then used as the dependent variable within an OLS regression model.

Union representation and employer engagement with them within the firm is estimated as a function of both time and country, enabling the three hypotheses to be tested. Dummy variables are created for each country, with the UK as the reference category and, for the four survey years, using 1991 as the base group. In addition, situational variables are included to reflect a range of factors likely to influence the extent of union representation and the extent to which employers engage with them at the workplace. These are: Firm's size, measured by the number of employees, since it is anticipated that larger firms are broadly more likely to engage with representative bodies; Sector, with a dummy variable indicating those organizations in the public sector, the expectation being that a union presence is more prevalent within the public sector, hence there is likely to be a positive correlation between the public sector dummy and union representation and the extent to which employers engage with them at the workplace; and finally, Industry, since it is likely that trade union representation and the extent to which employers engage with them at the workplace lends itself to typical modes of production in different industries, so a set of 15 industry dummies are included with metal manufacturing being used as the base group. The overall reference category for the model is a private sector metal manufacturing company in the UK surveyed in 1991. This decision reflects, firstly, that the UK represents the archetypical LME (i.e. an advanced case of one of the two mature varieties of capitalism), 1991 being the first year of survey data deployed in this study, whilst metal was traditionally core in manufacturing and remains heavily unionized (Doyle, 1985). .

\section{FINDINGS}

The focus of the empirical model is to estimate representativity/ engagement (RE) using a single measure and Table 2 records the key elements of the Mokken scale, constructed from each firms' responses to the four questions relating to RE. With a Cronbach's alpha greater than 0.7 and all 
of the Loevinger's H-coefficients greater than 0.3 as well as each of the correlations being greater than 0.3 , it is clear that the data is within the acceptable range for both reliability and scalability. As a result, it is a statistically valid step to use these measures to construct the Mokken scale, with the resultant scale being used as the dependent variable in the empirical model.

\section{TABLE 2 ABOUT HERE}

Table 3 records the mean values of the RE scale by year and country. At an observational level there is support at least for hypotheses $1,2 \mathrm{a}$ and $2 \mathrm{~b}$. The first hypothesis posits that there has been a decline in RE over this period and that national systems have become more alike. However, although we found a general decline in representation and the extent of employer engagement with them, important national differences have persisted; Hypothesis 1 is therefore not supported. Hypothesis 2 a proposed that the different types of economy were likely to be distinct in terms of the extent of RE; we found that this was indeed the case. However, a closer evaluation revealed much diversity within the CME category: the decline in RE was more pronounced in Germany (continental European CME) and the UK (LME) than in Sweden (social democratic capitalism), and thus confirming Hypothesis 2b. Not only were there persistent differences between LMEs and CMEs, but there was also considerable differences within the CME category.

The UK and Germany are within a similar range in terms of the relative decline of RE in evidence. However, in the case of Swedish firms, while a decline is in evidence, it is slower than the decline in the UK and Germany. We cannot therefore conclude that the decline is occurring at broadly the same rate; so, Hypothesis 3 is not supported.

\section{TABLE 3 ABOUT HERE}

However, before these findings can be confirmed, the extent to which RE reflects the situation faced by each individual firm needs to be established. Table 4 presents the results from estimating a regression model of RE as a function of a series of situational variables, plus time 
and country. The level of RE is significantly greater in public sector organizations, though this is not evident with respect to firm size. There is no evidence that larger firms experience greater RE. RE also varies across industries with some being more, or less, favorable to union activities. Within the model a number of industries, have significantly lower levels of RE than the metal manufacturing reference category (see Table 4).

\section{TABLE 4 ABOUT HERE}

Finally, the findings remain largely unaffected once the impact of the situational variables has been controlled for. There is a significant reduction in the level of RE between 1991 and 2009 and the size of that reduction increases wave by wave, but this has not led to broad similarity across national boundaries, as was suggested by H1. Sweden is significantly different from the UK with the German dummy being a long way from achieving any meaningful level of significance; in other words, whilst there was persistent difference between LMEs and CMEs (as suggested by $\mathrm{H} 2 \mathrm{a}$ ), a closer analysis revealed that much of the difference was due to the Swedish case, highlighting the nature of diversity with the CME category, as suggested by $\mathrm{H} 2 \mathrm{~b}$ ). In short, we found that national systems were all changing, in the same direction but not at a similar rate: there was difference, but the gap between different national systems varied with time since as discussed above the patterns of change are very different in Sweden than in the UK and Germany, suggesting that we cannot accept H3.

\section{DISCUSSION AND CONCLUSION}

This study of a large number of organizations with more than 100 employees across three crucial economies found that, at least amongst these larger organizations, there is little evidence of a convergence in practices. As such, it disproves both neo-liberal (e.g. Hansmann and Kraakman 2004) and more critical (e.g. Katz and Darbishire 2000) theories that systems are naturally converging on to a common model of weak unions and little in the way of collective bargaining. Rather, we found that context continues to mold both the incidence of unions and collective bargaining and mitigate (or accelerate) their decline. In this respect, a core institutional feature of social democratic capitalism is considerably more resilient than often predicted. Conversely, the 
decline of collective representation in an example of an LME has been particularly pronounced; employment relations in different national systems are not all individualizing at the same rate. The differences between Scandinavia and the continental European 'Rhineland' economies would also highlight the limitations of dichotomous Varieties of Capitalism models.

Hence, we conclude that Amable's (2003) multi-variety model of capitalism was a more accurate predictor of the incidence and nature of collective representation than a simple dichotomous one; there are, as he suggests, some important differences between what goes on in the Scandinavian social democracies and in continental/ 'Rhineland' Europe. In addition, different national systems are changing at different rates. Although we found evidence of individualization in Germany, as suggested in other accounts (Streeck 2001 ), some of our findings support other studies indicating that in other areas, such as the market for corporate control and training, the national model has been strengthened, not weakened (Thelen 2014). The comparative capitalisms literature is developing but the basic principle that models are distinct and unlikely to lose their distinction seems to have some validity. This would suggest that national institutions are not closely or perfectly coupled, and that reform is possible in one area without endangering systemic coordination in another. This highlights the complex nature of capitalist diversity (Walker, Brewster and Wood 2015), and the fundamental distinctions that persist between mature institutional environments. Clearly the decline of collectivism has been massively affected by the socio-economic conditions of the specific countries and there seems to be little sign of convergence. Despite being the product of a clear failure of neo-liberalism, the 2008-economic crisis appears to have accelerated the pace of neo-liberal reforms across a wide range of national contexts; yet, there remains little sign of coherent convergence. This study only looks at a single defining feature of national contexts; however, changes in other areas suggests contradictory and uneven pressures in any tendencies to systemic liberalization. Not only are national systems evolving in complex and dynamic fashions, but the relative pace of change varies between national settings.

It may be that smaller organizations not included in our database do not follow the pattern of the larger exemplars that are: Perhaps the most significant limitation on our data is that we are restricted to organizations with more than 100 employees. This, however, in one sense 
strengthens our argument. As Roberts $(2003,37)$ notes, in most small firms, union penetration is minimal, and the process of interaction between managers and workers is informal. Further, our data are drawn from the most senior executive in each organization: arguably, they might be the people who would have the best access to the necessary data and the deepest knowledge of organizational HRM policies (Huselid and Becker 2000), but it would be valuable in future research to check their perceptions against those of trade union leaders and members. However, despite these limitations, the findings do allow us to draw significant conclusions about the comparative capitalisms antecedents of developments in unionization. 


\section{REFERENCES}

Amable, B. 2003. The Diversity of Modern Capitalism. Oxford: Oxford University Press.

Boyer, R. 2006. "How do Institutions Cohere and Change." In Institutions, Production and Working Life, eds. G. Wood and P. James, 13-61. Oxford: Oxford University Press.

Brewster, C., W. Mayrhofer and M.J. Morley (eds). 2004. Human Resource Management in Europe: Evidence of Convergence? London: Butterworth Heinemann.

Brewster, C., M. Brookes and G. Wood. 2006. "Varieties of Firm." In Institutions, Production and Working Life, eds. G. Wood and P. James, 217-234. Oxford: Oxford University Press.

Brewster, C., G. Wood, R. Croucher and M. Brookes. 2007. "Collective and Individual Voice: Convergence in Europe?" International Journal of Human Resource Management 18 (7):12461262.

Checchi, D. and J. Visser. 2005. "Pattern Persistence in European Trade Union Density: A Longitudinal Analysis 1950-1996.” European Sociological Review 21 (1):1-21.

Colvin, A. J.S. 2003. "Institutional Pressures, Human Resource Strategies, and the Rise of Nonunion Dispute Resolution Procedures." Industrial and Labor Relations Review 56 (3):375392.

Crouch, C. 2005. "Three Meanings of Complementarity.” Socio-Economic Review 3 (2):359363.

Creswell, J.W. 2003. Research Design: Quantitative, Qualitative and Mixed Approaches. London: Sage.

Doellgast, V., U. Holtgrewe and S. Deery. 2009. "The Effects of National Institutions and Collective Bargaining Arrangements on Job Quality in Front-Line Service Workplaces." Industrial and Labor Relations Review 62 (4):489-509.

Doellgast, V. 2008. "Collective Bargaining and High-Involvement Management in Comparative Perspective: Evidence from U.S. and German Call Centers.” Industrial Relations 47 (2):284-319.

Dore, R. 2000. Stock Market Capitalism: Welfare Capitalism. Cambridge: Cambridge University Press.

Doyle, P.M., 1985. Area wage surveys shed light on declines in unionization. Monthly Labor Review, 108:13-20.

Friedman, M. 1992. “Do Old Fallacies Ever Die?” Journal of Economic Literature 30 (4):21292132. 
Godard, J. 2006. “The US and Canadian Unions: Markets vs States and Society.” In Trade Unions and Democracy, eds. M. Harcourt and G. Wood, Manchester: Manchester University Press, pp159-190.

Godard, J. 2003. "Do Labor Laws Matter? The Density Decline and Convergence Thesis Revisited." Industrial Relations 42 (3):458-492.

Hall, P. and D. Soskice. 2001. “An Introduction to the Varieties of Capitalism.” In Varieties of Capitalism: The Institutional Basis of Competitive Advantage, eds. P. Hall and D. Soskice, 2127. Oxford: Oxford University Press.

Hancke, B., M. Rhodes and M. Thatcher. 2007. "Introduction: Beyond Varieties of Capitalism." In Beyond Varieties of Capitalism, eds. B. Hancke, M. Rhodes, and M. Thatcher, Oxford: Oxford University Press, pp. 1-41.

Hansmann, H. and R. Kraakman. 2003. "The End of History for Corporate Law." In Convergence and Persistence in Corporate Governance, eds. J. Gordon and M. Roe, 49-78. Cambridge: Cambridge University Press.

Hollingsworth, J.R. 2006. "Advancing our Understanding of Capitalism with Niels Bohr's Thinking about Complementarity." In Institutions and Working Life, eds. P. James and G. Wood, 62-82. Oxford: Oxford University Press.

Huselid, M. A. and B.E. Becker. 2000. "Comment on 'Measurement Error in Research on Human Resources and Firm Performance: How Much Error is There and How Does it Influence Effect Size Estimates' by Gerhart, Wright, McMahan and Snell.” Personnel Psychology 53 (4): 835-845.

Katz, H. and I. Darbishire. 2000. Converging Divergences: Worldwide Changes in Employment Systems. Ithaca: ILR Press.

Kaufman, B. 2004. "What Unions Do: Insights from Economic Theory." Journal of Labor Research 25 (3):351-382.

Lane, C. and G. Wood. 2009. "Introducing Diversity in Capitalism and Capitalist Diversity." Economy and Society 38 (4):531-551.

Lincoln, J. and A. Kalleberg. 1990. Culture, Control and Commitment: A Study of Work Organization in the United States and Japan. Cambridge: Cambridge University Press.

Marsden, D. 1999. A Theory of Employment Systems. Oxford: Oxford University Press.

Marsden, D. 2001. "Change in Employment Systems: Do Common International Trends Imply a Common Destination.” Industrial and Labor Relations Review 54 (3):682-688. 
Mayrhofer, W. and C. Brewster. 2005. "European Human Resource Management: Researching Developments over Time." Management Revue 16 (1):36-62.

Mayrhofer, W., C. Brewster, M.J. Morley and J. Ledolter. 2011. "Hearing a Different Drummer? Evidence of Convergence in European HRM." Human Resource Management Review 21 (1):5067.

Mayrhofer, W., M. Müller-Camen, J. Ledolter, G. Strunk and C. Erten. 2002. "The Diffusion of Management Concepts in Europe - Conceptual Considerations and Longitudinal Analysis." European Journal of Cross-Cultural Competence \& Management 3 (1):315-349.

Moody, K. 1997. Workers in a Lean World. London: Verso Books.

Roberts, I. 2003. "Sociology and Industrial Relations." In Understanding Work and Employment Relations, eds. Ackers, P. and A. Wilkinson, 31-42. Oxford: Oxford University Press.

Streeck, W. 2001. "High Inequality, Low Activity: The Contribution of the Social Welfare System to the German Collective Bargaining Regime." Industrial and Labor Relations Review 54 (3):698-706.

Thelen, K. 2014. Varieties of Liberalization and the New Politics of Social Solidarity. Cambridge: Cambridge University Press.

Thelen, K. 2009. "Institutional Change in Advanced Political Economies." British Journal of Industrial Relations 47 (3):499-520.

Thelen, K. 2001. "Varieties of Labor Politics in the Developed Democracies." In Varieties of Capitalism: The Institutional Basis of Competitive Advantage, eds. P. Hall and D. Soskice, 7692. Oxford: Oxford University Press.

Thomas, J. 1993. Doing Critical Ethnography. London: Sage.

Thompson, P. and M. Alvesson. 2005. "Bureaucracy at Work: Misunderstandings and Mixed Blessings.” In The Values of Bureaucracy, ed. Du Gay, P., 121-140. Oxford: Oxford University Press.

Tregaskis, O. and C. Brewster. 2006. "Converging or Diverging? A Comparative Analysis of Trends in Contingent Employment Practice in Europe over a Decade." Journal of International Business Studies 37 (1):111-126.

Turner, L. 2009. "Institutions and Activism: Crisis and Opportunity for a German Labor Movement in Decline." Industrial and Labor Relations Review 62 (3):294-312.

Walker, J. T., C. Brewster and G. Wood. 2014. "Diversity Between and Within Varieties of Capitalism: Transnational Survey Evidence." Industrial and Corporate Change 23 (2):493-533. 
Whitley, R. 1999. Divergent Capitalisms: The Social Structuring and Change of Business Systems. Oxford: Oxford University Press.

Wilkinson, A., Wood, G.T., and Deeg, R. 2014. The Oxford Handbook of Employment Relations. Oxford, Oxford University Press

Wilthagen, T. and F. Tros. 2004. "The Concept of 'Flexicurity': A New Approach to Regulating Employment and Labour Market Transfers. " European Review of Labour and Research 10 (2):166-186.

Wright, E. and R. Dwyer. 2006. "The Pattern of Job Expansions in the USA.” In Institutions, Production and Working Life, eds. G. Wood and P. James, 275-314. Oxford: Oxford University Press. 
TABLE 1 Breakdown of data sample

\begin{tabular}{ccccc}
\hline & UK & Germany & Sweden & Total \\
\hline 1991 & 1508 & 967 & 295 & 2770 \\
1995 & 1178 & 383 & 344 & 1905 \\
1999 & 1091 & 503 & 352 & 1946 \\
2003 & 1115 & 320 & 383 & 1818 \\
2009 & 218 & 420 & 282 & 920 \\
\hline Total & 5110 & 2593 & 1656 & 9359 \\
\hline
\end{tabular}


TABLE 2: Mokken Scale of union representation and the extent to which employers engage with them at the workplace (RE)

\begin{tabular}{lcccc}
\hline & & Mean & $\mathrm{H}_{\text {wgt }}$ & Corr. \\
\hline Scale & $\begin{array}{c}\text { Overall calculative scale, 4 items } \\
\text { (Cronbach's alpha =0.72) }\end{array}$ & & 0.71 & 0.41 \\
\hline Item 1 & $>50 \%$ union membership & 0.38 & 0.83 & 0.39 \\
Item 2 & Perceive union has influence & 0.82 & 0.69 & 0.57 \\
Item 3 & $\begin{array}{c}\text { Management communicate } \\
\text { through TU reps }\end{array}$ & 0.81 & 0.60 & 0.48 \\
Item 4 & $\begin{array}{c}\text { Employees communicate views } \\
\quad \text { through TU reps }\end{array}$ & 0.72 & 0.74 & 0.65 \\
& & & & \\
\hline
\end{tabular}


TABLE 3 Mean values of RE scale

\begin{tabular}{ccccc}
\hline & UK & Germany & Sweden & Total \\
\hline 1991 & 60.98 & 58.86 & 94.21 & 63.78 \\
1995 & 58.57 & 58.82 & 95.09 & 65.21 \\
1999 & 45.82 & 49.77 & 92.91 & 55.36 \\
2003 & 39.33 & 40.73 & 90.01 & 50.25 \\
2009 & 26.15 & 31.23 & 84.64 & 46.40 \\
\hline Total & 50.98 & 50.38 & 91.52 & 58.76 \\
\hline
\end{tabular}


TABLE 4 OLS model of RE

\begin{tabular}{|c|c|c|c|}
\hline Variable & Coefficient & t-ratio & Mean \\
\hline Constant & $63.34 * * *$ & 74.58 & \\
\hline Total employees (000's) & 0.00 & 1.03 & 3.98 \\
\hline Public sector & $14.69 * * *$ & 13.63 & 0.21 \\
\hline Agriculture, hunting, forestry, fishing & $-14.30 * * *$ & -4.18 & 0.01 \\
\hline Energy and water & 1.49 & 0.84 & 0.03 \\
\hline Chemical products & $-3.51 * *$ & -2.25 & 0.04 \\
\hline Other manufacturing & 1.54 & 1.56 & 0.16 \\
\hline Building and civil engineering & $-17.26 * * *$ & -9.92 & 0.03 \\
\hline Retail and distribution & $-22.56 * * *$ & -18.34 & 0.08 \\
\hline Transport and communication & $-4.26 * * *$ & -2.78 & 0.05 \\
\hline Banking, finance, insurance & $-27.39 * * *$ & -24.52 & 0.11 \\
\hline Personal, domestic, recreational services & $-30.92 * * *$ & -8.18 & 0.01 \\
\hline Health services & -1.68 & -1.00 & 0.05 \\
\hline Other services & $-13.63 * * *$ & -9.16 & 0.05 \\
\hline Education & $-5.72 * * *$ & -3.25 & 0.04 \\
\hline Public Administration & $-3.98 * * *$ & -2.66 & 0.09 \\
\hline Other & $-9.97 * * *$ & -6.56 & 0.05 \\
\hline 1995 & $-1.71 * *$ & -2.05 & 0.21 \\
\hline 1999 & $-10.25^{* * *}$ & -12.10 & 0.20 \\
\hline 2003 & $-16.22 * * *$ & -18.47 & 0.19 \\
\hline 2009 & $-22.70 * * *$ & -19.88 & 0.09 \\
\hline Germany & 0.721 & 0.99 & 0.28 \\
\hline Sweden & $39.92 * * *$ & 48.00 & 0.18 \\
\hline Dependent Variable & RE Scale & & \\
\hline Mean & 58.76 & & \\
\hline Observations & 9359 & & \\
\hline R-squared & 0.37 & & \\
\hline F Stat. & 237.06 & & \\
\hline
\end{tabular}

$*, * *$ and $* * *$ denotes significance at the 10,5 and $1 \%$ levels respectively.

${ }^{\mathrm{i}}$ In fact he uses all the Nordic countries in his Scandinavian category. 